\title{
Correction of Soil Acidity in an Organic System of Shadowed Coffee
}

\author{
Victor Casimiro Piscoya ${ }^{1^{*}}$, Cristiane Maria Gonçalves Crespo ${ }^{1}$, \\ Renisson Neponuceno de Araújo Filho², Julyane Silva Mendes Policarpo', \\ Nayane Laisa de Lima Cavalcanti ${ }^{1}$, Taiza Karla Alves Souza1, \\ Alex Souza Moraes ${ }^{1}$, Moacyr Cunha Filho', Gabriel Carlos Moura Pessoa1, \\ Robson Carlos Pereira de Melo', Rosangela Gomes Tavares', \\ Thaiana Brunes Feitosa ${ }^{1}$, Milton Marques Fernandes ${ }^{3}$, \\ Raimundo Rodrigues Gomes Filho ${ }^{3}$, João Lucas Aires Dias ${ }^{2}$ \\ and Luiz Diego Vidal Santos ${ }^{3}$ \\ ${ }^{1}$ Federal University Rural of Pernambuco, Rua Dom Manoel of Medeiros, s/n, Dois Irmãos, \\ CEP 52171-900, Recife, PE, Brazil. \\ ${ }^{2}$ Federal University of Tocantins, Rua Badejós, Lote 7, Chácaras 69/72, s/n - Zona Rural, \\ CEP 77402-970, Gurupi, TO, Brazil. \\ ${ }^{3}$ Federal University of Sergipe, Av. Marechal Rondon, s/n, CEP 49100-000, Jardim Rosa Elze,
} São Cristóvão - SE, Brazil.

Authors' contributions

This work was carried out in collaboration among all authors. Authors CMGC, VCP and JSMP conducted the study, collected the analyzes in the field and did the statistical analysis of the data, wrote the protocol and wrote the first draft of the manuscript. Authors NLLC, TKAS, ASM, MCF and GCMP designed the study and monitored and supervised all of this study. Authors RCPM, RGT, TBF and MMF assisted in literature searches, writing in

the manuscript and discussing the data. Authors RNAF, RRGF, JLAD and LDVS helped in the search of the literature and in the translation of the same into English language. All authors read and approved the final manuscript.

Article Information
DOI: $10.9734 / A R R B / 2021 / v 36 i 1030432$ Editor(s):
(1) Dr. Md. Aminur Rahman, Jashore University of Science and Technology, Bangladesh.
(1) Owere, Lawrence, National Agricultural Research Organisation, Uganda. (2) Radhey Shyam Singh, Mandan Bharti Agriculture College, India. (3) Amrita A. Vasava, Kamdhenu University, India. Complete Peer review History: https://www.sdiarticle4.com/review-history/73981

Original Research Article

Received 02 August 2021

Accepted 08 October 2021 Published 11 October 2021

\begin{abstract}
Through sustainable agriculture it is possible to explore the coffee culture in consortium with native forests in more rugged reliefs, as coffee is a permanent crop in addition to the climatic conditions offered by the swamps that favor its development. Given the above, the present work proposes,
\end{abstract}


based on the acidity results, to quantify the need for correctives in the soil to obtain a better nutritional use offered by agroforestry cultivation of organic coffee in the shade with favorable results to increase productivity and, consequently, the farmer's profit. The research was carried out at the Várzea da Onça farm, in the Yaguara Ecological Complex, located in the municipality of Taquaritinga do Norte, Borborema plateau, in the Agreste Pernambuco mesoregion. Altitude, it is necessary to adopt appropriate management techniques that guarantee production, soil conservation and biodiversity, proposing soil correction to guarantee the ideal nutritional conditions for coffee growth. For this purpose, soil samples were collected in the Top (T), Hillside (E) and Pedimento $(P)$ ranges at depths of $0-20,20-40$ and $40-60 \mathrm{~cm}$ when planting shaded coffee and soil samples from Native Forest (MN) preserved and legally protected from the Brejo de Taquaritinga. Active, exchangeable and potential acidity were analyzed, as well as the sum of bases, the potential and effective cation exchange capacity, base saturation and aluminum saturation. The results obtained were subjected to analysis of variance and the means were tested at $5 \%$ by the Tukey test. A potential of the system was found with low to very low natural fertility, with a strongly acidic reaction. Thus, adequate soil management and correction techniques are necessary for the crop to absorb all the nutrients made available by the organic matter present on the surface, concluding that all slopes require liming, the slope of Hillside and Mata Nativa they also need plastering for the culture to develop properly.

Keywords: Soil correction; shaded coffee; marsh altitude.

\section{INTRODUCTION}

Brazilian soils in general are considered acidic, with a pH below 5 and predominate in most tropical and subtropical regions, limiting the growth of different cultures. The sustainability of these soils in these areas depends on the correct management of soil acidity [1]. PH values below the optimal range of $5.5-6.5$ can increase the concentrations of potentially toxic elements, such as aluminum (Al) and manganese (Mn), affecting the availability of nutrients to plants. Liming is the method of correcting soil acidity commonly used through the addition of $\mathrm{Ca}^{2+}, \mathrm{Mg}^{2+}$ in order to raise the $\mathrm{pH}$, decreasing the leaching of $\mathrm{K}$ the fixation of $\mathrm{P}$ increasing the availability of $\mathrm{B}, \mathrm{Mn}^{2+}$, $\mathrm{Zn}$ and Mo which stimulating microbial activity, accelerating the decomposition of organic matter, improving soil conditions for the action of nitrogen-fixing bacteria, which can induce the movement of $\mathrm{Ca}$ and $\mathrm{Mg}$ at greater depths [2].

In the agro-ecosystem, the proper functioning of the soil is crucial, in order to guarantee the productive capacity [3]. For this, from a soil analysis, there is a need to correct fertility and hydrogen potential $(\mathrm{pH})$ [4], since acidic soils restrict the production of cultivated species [5]. Another method, which according to [2] is not exactly used to correct soil acidity, it is the application of agricultural plaster $(\mathrm{CaSO} 4.2 \mathrm{H} 2 \mathrm{O})$ in the soil, which, in the presence of moisture, undergoes dissolution and the $\mathrm{Ca}^{2+}, \mathrm{K}^{+}$and $\mathrm{Mg}^{2+}$ ions form new compounds of greater mobility, reaching greater depths along the profile, making calcium available and neutralizing aluminum. The addition of lime can be combined with plaster to improve soil nutrients and agricultural productivity, as noted by [1] in intercropped cultivation of corn and grasses in tropical sandyclay soil, where there was an increase in fertility, nitrogen-fixing microorganisms, in addition to increasing the availability of $\mathrm{Ca}^{2}+$ and $\mathrm{Mg}^{2+}$ and reducing $\mathrm{Al}^{3+}$ levels.

[6] also found that, in soil with high acidity and low levels of exchangeable bases under Pinus taeda plantation, in the state of Paraná, Brazil, liming induced an increase in $\mathrm{pH}, \mathrm{Ca}^{2+}$ and $\mathrm{Mg}^{2+}$ reducing the levels of $\mathrm{Al}^{3+}$ and saturation through $\mathrm{Al}$, up to $0.10 \mathrm{~m}$ deep. As noted by [7], the application of lime in no-tillage systems reduced the acidity of the soil in the most superficial layers (up to $0.05 \mathrm{~m}$ ) more sharply, and less accentuated in the subsoil layers $(0.05-0,10 \mathrm{~m})$. It is important to note that the excessive use of limestone applications to raise the $\mathrm{pH}$ can cause negative interactions in the ion exchange complex, with a consequent nutritional imbalance [8].

It is therefore essential to measure the need for adequate liming to be applied in the intended cultivation system. To recognize the importance of sustainable agriculture, it is necessary to assess soil fertility and management practices adopted in an agroecological system capable of developing agriculture that is environmentally sustainable, productive and economically viable, valuing the local and empirical knowledge of farmers, socialization of this knowledge and its application to the common objective of 
sustainability [9] in the conservation or restoration of the physical and chemical properties of the soil, in order to maintain its productivity [10].

Before implanting a crop, soil sampling is the first and most critical step in a good soil correction and fertilization program. Liming promotes an important change in the root environment, as it reduces soil acidity, provides $\mathrm{Ca}$ and $\mathrm{Mg}$ and increases availability and efficiency in the use of various nutrients [11] has an effect on coffee productivity, on the quality of the bean and on the relationship between management and productivity at the same time, [2] characterizes soil correction as an alternative to increase coffee productivity. Given the above, the present work proposes, based on the acidity results, to quantify the need for correctives in the soil to obtain a better nutritional use offered by agroforestry cultivation of organic coffee in the shade with favorable results to increase productivity and, consequently, the farmer's profit.

\section{MATERIALS AND METHODS}

\subsection{Study Area}

The research was carried out at the Várzea da Onça farm, in the Conceição do Complexo da Yaguara Ecológico area (Fig. 1), inserted in the municipality of Taquaritinga do Norte, a geoenvironmental unit on the Borborema plateau, mesoregion of Agreste Pernambuco and microregion of Alto Capibaribe. The farm has active production of organic coffee in an agroecological shaded coffee system, with 150 ha, with the sample portion of the study 25 ha, located on the banks of PE-130, approximately $12 \mathrm{~km}$ from PE-104.
The region has an Aw climate, with dry winter, according to the KÖPPEN classification [12]. According to the State Water and Climate Agency (APAC), the region has an average annual rainfall of $721 \mathrm{~mm}$, with the highest rainfall recorded between February and August. It has an average annual temperature of $21^{\circ} \mathrm{C}$ and an altitude between $736 \mathrm{~m}$ and $1,100 \mathrm{~m}$, being considered according to [13], as a swamp area of altitude, due to its geomorphological properties, with plateaus and plateaus between $500-100 \mathrm{~m}$ altitude, associated with the physical properties of the Caatinga biome, forming the formation of small islands of Atlantic forest.

The relief ranges from smooth undulating to strong undulating with sometimes steep slopes, with altitudes between $750 \mathrm{~m}$ and $1,000 \mathrm{~m}$ [14]. The soil is classified as a typical eutrophic red yellow argisol, medium / clay texture, with an A horizon prominent, subperennial forest and mountainous relief, according to Embrapa methodology [15].

\subsection{Soil Analysis}

Soil samples were collected in the Top $(T)$, Hillside $(E)$ and Pedimento $(P)$ ranges at depths of $0-20,20-40$ and $40-60 \mathrm{~cm}$ when planting shaded coffee and soil samples from Mata Nativa ( $M N)$, as shown in Table 1. Active, exchangeable and potential acidity were analyzed, in addition to the sum of bases, capacity of effective and potential cation exchange, base saturation and aluminum saturation, using the EMBRAPA methodology [15] in order to compare with the Liming and Fertilization Recommendation Manual for the State of Espírito Santo.

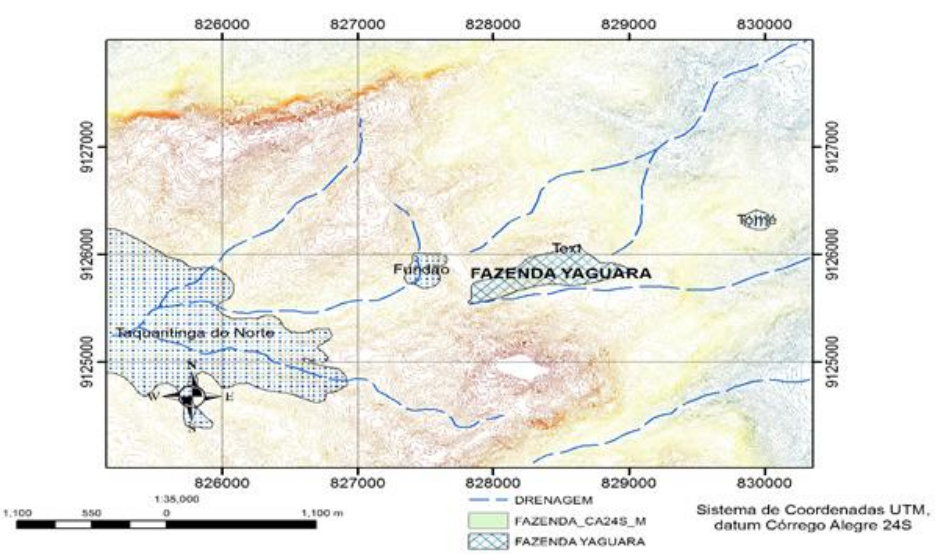

Fig. 1. Location map of the study area, Yaguara Ecológico farm in the municipality of Taquaritinga do Norte-PE 
Table 1. Parameters and their respective classes of interpretation of soil fertility according to Prezotti (2013), with adaptations

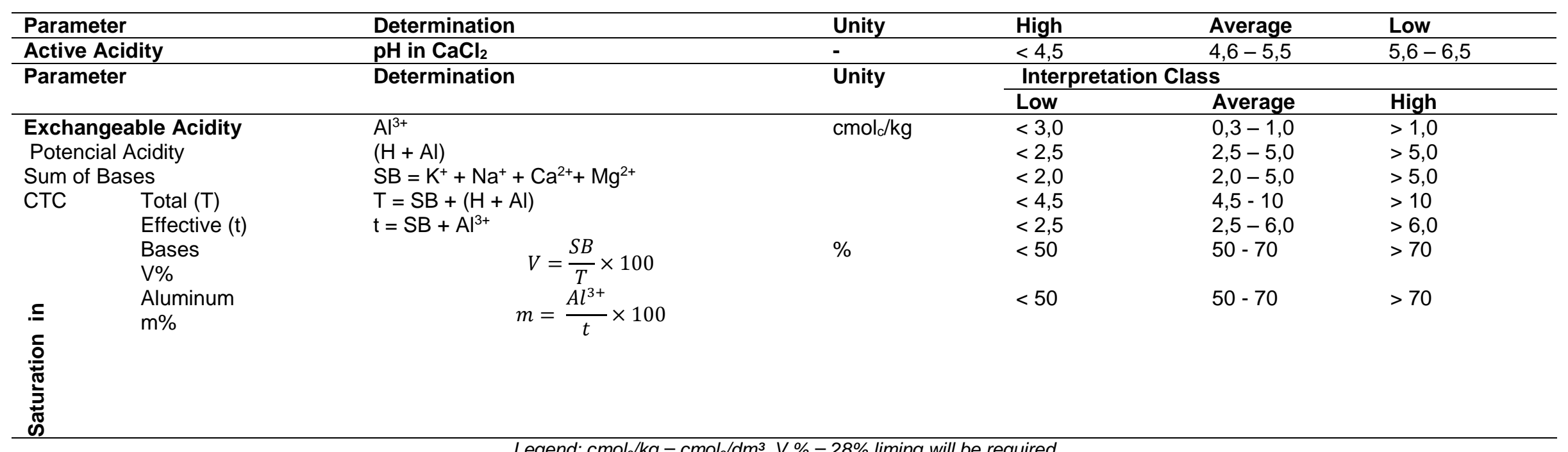




\subsection{Soil Correction}

In order to determine the liming requirement (NC) equation 1 , the corrective products sold close to the study area were identified with a $65 \%$ Total Limestone Relative Power, through the combination of effects between the neutralizing value and efficiency relative from the concealer calcium oxide $(\mathrm{CaO})$ and magnesium oxide (MgO) concentrations.

$$
N C=\left\{\left[\frac{V_{2}-V_{1}}{100}\right] \times T \times \frac{100}{P R N T}\right\}
$$

Where, NC liming need; V1 base saturation V\% of soil analysis; V2 base saturation V\% desired for coffee according to technical bulletin (V2 = $70 \%)$; T is CTC; PRNT (\%) is the Relative Power of Total Limestone Neutralization (PRNT $=65 \%$ ).

It was necessary to determine the amount of necessary corrective (QC) using equation 2 , so that the efficiency of the PRNT to $100 \%$ is reached. The correction will take place at a depth of up to $7 \mathrm{~cm}$. The method proposed by Mesquita (2016) aims to raise the base saturation to the desired value while correcting the acidity.

$$
Q C=N C \times\left(\frac{S C}{100}\right) \times\left(\frac{P F}{20}\right) \times\left(\frac{100}{P R N T}\right)
$$

Where, QC Lime quantity in $\mathrm{t} / \mathrm{ha}$; SC is the land surface to be covered with limestone in\%; PF Depth of limestone incorporation in centimeters; PRNT (\%) Relative Power of Total Limestone Neutralization.

In the case of areas studied have aluminum saturation $(\mathrm{m} \%)$ greater than $30 \%$, it will be necessary to determine the need for plaster (NG) using equation 3 , proposed by [2]. The addition of gypsum corresponds to $25 \%$ of the NC in the layer.

$$
N G=0,25 \times N C
$$

Where NG is the need for plaster;

Equation 4 was used to calculate the amount of gypsum (QG).

$$
Q G=N G \times \frac{S C}{100} \times \frac{E C}{20}
$$

Where QG quantity of plaster; SC covering surface of the plaster application; EC thickness of the subsurface layer to be corrected.

\section{RESULTS AND DISCUSSION}

Active Acidity varied from medium to high [16] with an average Top rating at all depths (Table 2). A similar behavior was observed in the Encosta, Pedimento and Nativa Forest (classified with high acidity), both in the strips and in the depths. The Exchangeable Acidity presented a high classification in all the Slope and Native Forest depths and a low classification in the Topo and Pedimento in the $0-20 \mathrm{~cm}$ depths. These results demonstrate the influence of toposequence on the decreasing variation of concentration. Potential Acidity presents a variation of average at the top and in the pediment, and high on the slope and in the native forest at all depths.

The Sum of Bases remains high at the top at depths of $0-20 \mathrm{~cm}$ and $20-40 \mathrm{~cm}$ and average at 40-60 cm, low on the slope at all depths and average at the first depths and low in native forest. Effective and potential CTC is average at all depths and slopes, being high at the top at 0 $20 \mathrm{~cm}$ depth and $20-40 \mathrm{~cm}$ at potential acidity. Base and aluminum saturations vary from low to medium, being the native forest with a low class in relation to the organic system. The results suggest the natural dynamics of the soil, in which the content of nutrient cations and the reactivity of the sorting complex are related to topographical variation, where constant base leaching and soil disaggregation processes make it susceptible to erosion. The chemical composition of rocks and relief directly affect soil nutrient stocks [17].

The organic matter present in the organic system leaves the soil acidic and does not allow nutrients to be made available for plant development, impairing the development of the root system by having aluminum in toxic form. This happens because the presence of this element weakens and reduces root growth, interfering with the plant's ability to extract and absorb nutrients (such as $\mathrm{P}, \mathrm{Mg}, \mathrm{Ca}$ and K) [18]. Aluminum stress increases the molecular mass of hemicellulose in the cell wall, making it rigid, inhibiting root elongation [19].

The liming requirement was determined for each analyzed soil depth and slope of the study area (Table 3). 
Table 2. Active, exchangeable and potential acidity; sum of bases; effective and potential CTC; base saturation and aluminum saturation in the depth of $0-20 \mathrm{~cm}, 20-40 \mathrm{~cm}, 40-60 \mathrm{~cm}$

\begin{tabular}{|c|c|c|c|c|c|c|c|c|}
\hline \multirow{3}{*}{$\begin{array}{l}\text { Depth } \\
\text { Slope }\end{array}$} & \multicolumn{3}{|l|}{ Acidez } & \multirow{3}{*}{$\begin{array}{l}\text { Sum de } \\
\text { Bases }\end{array}$} & \multicolumn{2}{|l|}{ CTC } & \multirow{2}{*}{\multicolumn{2}{|c|}{ Saturation by }} \\
\hline & Active & Exchangeable & Potential & & Effective (t) & Potential (T) & & \\
\hline & $\mathrm{pH}$ & Al & $\mathrm{H}+\mathrm{Al}$ & & $\mathrm{t}=\mathrm{SB}+\mathrm{Al}^{3+}$ & $\mathrm{T}=\mathrm{SB}+(\mathrm{H}+\mathrm{Al})$ & bases (V) & aluminium $(\mathrm{m})$ \\
\hline $0-20 \mathrm{~cm}$ & & $\mathrm{cmol}_{\mathrm{c} \mathrm{kg}}{ }^{-1}$ & & & & & $-\%$ & \\
\hline Top & $5,19 \mathrm{Aa}-\mathrm{M}$ & $0,11 \mathrm{Ca}-\mathrm{B}$ & $4,60 \mathrm{Ba}-\mathrm{M}$ & $7,93 \mathrm{Aa}-\mathrm{A}$ & $8,05 \mathrm{Aa}-\mathrm{A}$ & $12,54 \mathrm{Aa}-\mathrm{A}$ & $63,23 \mathrm{Aa}-\mathrm{M}$ & $1,46 \mathrm{Ca}-\mathrm{B}$ \\
\hline Slope & $4,11 \mathrm{Ba}-\mathrm{E}$ & $1,91 \mathrm{Aa}-\mathrm{A}$ & $7,75 \mathrm{Aa}-\mathrm{A}$ & $1,35 \mathrm{Ba}-\mathrm{B}$ & $3,27 \mathrm{Ba}-\mathrm{M}$ & $9,11 \mathrm{Ba}-\mathrm{M}$ & $14,7 \mathrm{Ba}-\mathrm{B}$ & $59,34 \mathrm{Aa}-\mathrm{M}$ \\
\hline Request & $4,23 \mathrm{Ba}-\mathrm{E}$ & $0,08 \mathrm{Ca}-\mathrm{B}$ & $3,85 \mathrm{Ca}-\mathrm{M}$ & $4,00 \mathrm{Ca}-\mathrm{M}$ & $4,08 \mathrm{Ba}-\mathrm{M}$ & $7,86 \mathrm{Ba}-\mathrm{M}$ & $50,91 \mathrm{Aa}-\mathrm{M}$ & $2,01 \mathrm{Ca}-\mathrm{B}$ \\
\hline $\begin{array}{l}\text { Native Forest } \\
20-40 \mathrm{~cm}\end{array}$ & $4,12 \mathrm{Ba}-\mathrm{E}$ & $1,32 \mathrm{Ba}-\mathrm{A}$ & $7,41 \mathrm{Aa}-\mathrm{A}$ & $1,94 \mathrm{Ca}-\mathrm{B}$ & $3,26 \mathrm{Ba}-\mathrm{M}$ & $9,36 \mathrm{Ba}-\mathrm{M}$ & $20,74 \mathrm{Ba}-\mathrm{B}$ & $40,46 \mathrm{Ba}-\mathrm{B}$ \\
\hline Top & $5,27 \mathrm{Aa}-\mathrm{M}$ & $0,09 \mathrm{Da}-\mathrm{A}$ & $4,76 \mathrm{Ba}-\mathrm{M}$ & $5,83 A b-A$ & $5,92 \mathrm{Ab}-\mathrm{M}$ & $10,59 \mathrm{Ab}-\mathrm{A}$ & $55,04 \mathrm{Aa}-\mathrm{M}$ & $1,56 \mathrm{Da}-\mathrm{B}$ \\
\hline Slope & $4,13 \mathrm{Ba}-\mathrm{E}$ & $1,89 \mathrm{Aa}-\mathrm{A}$ & $7,67 \mathrm{Aa}-\mathrm{A}$ & $1,14 \mathrm{Ba}-\mathrm{B}$ & $3,04 \mathrm{Ba}-\mathrm{M}$ & $8,81 \mathrm{Aa}-\mathrm{M}$ & $12,97 \mathrm{Ba}-\mathrm{B}$ & $62,83 \mathrm{Ab}-\mathrm{M}$ \\
\hline Request & $4,17 \mathrm{Ba}-\mathrm{E}$ & $0,63 \mathrm{Ca}-\mathrm{M}$ & $3,57 \mathrm{Cab}-\mathrm{M}$ & $2,86 \mathrm{Bab}-\mathrm{M}$ & $3,50 \mathrm{Ba}-\mathrm{M}$ & $6,43 \mathrm{Bab}-\mathrm{M}$ & $43,95 \mathrm{Aa}-\mathrm{M}$ & $18,64 \mathrm{Cb}-\mathrm{B}$ \\
\hline $\begin{array}{l}\text { Native Forest } \\
40-60 \mathrm{~cm}\end{array}$ & $4,18 \mathrm{Ba}-\mathrm{E}$ & $1,48 \mathrm{Bb}-\mathrm{A}$ & $7,59 \mathrm{Aa}-\mathrm{A}$ & 1,52 Ba - M & $3,00 \mathrm{Ba}-\mathrm{M}$ & $9,11 \mathrm{Aa}-\mathrm{M}$ & $16,63 \mathrm{Ba}-\mathrm{B}$ & $49,17 \mathrm{Bb}-\mathrm{B}$ \\
\hline Top & $5,41 \mathrm{Aa}-\mathrm{M}$ & $0,09 \mathrm{Da}-\mathrm{B}$ & $4,45 \mathrm{Ba}-\mathrm{M}$ & $4,80 \mathrm{Ab}-\mathrm{M}$ & $4,90 \mathrm{Ab}-\mathrm{M}$ & $9,25 \mathrm{Ab}-\mathrm{M}$ & $51,9 \mathrm{Aa}-\mathrm{M}$ & $1,99 \mathrm{Ca}-\mathrm{B}$ \\
\hline Slope & $4,34 \mathrm{Ba}-\mathrm{E}$ & $1,85 \mathrm{Ba}-\mathrm{A}$ & $7,63 \mathrm{Aa}-\mathrm{A}$ & $0,77 \mathrm{Ba}-\mathrm{B}$ & $2,63 \mathrm{Ba}-\mathrm{M}$ & $8,41 \mathrm{Aa}-\mathrm{M}$ & $9,24 \mathrm{Ca}-\mathrm{B}$ & $70,49 \mathrm{Ab}-\mathrm{A}$ \\
\hline Request & $4,24 \mathrm{Ba}-\mathrm{E}$ & $0,62 \mathrm{Cb}-\mathrm{M}$ & $4,24 \mathrm{Bb}-\mathrm{M}$ & $1,34 \mathrm{Bb}-\mathrm{B}$ & $1,96 \mathrm{Bb}-\mathrm{M}$ & $5,58 \mathrm{Bb}-\mathrm{M}$ & $23,97 \mathrm{Bb}-\mathrm{B}$ & $31,7 \mathrm{Bc}-\mathrm{B}$ \\
\hline Native Forest & $4,06 \mathrm{Ba}-\mathrm{E}$ & $2,37 \mathrm{Ab}-\mathrm{A}$ & $7,51 \mathrm{Aa}-\mathrm{A}$ & $0,88 \mathrm{Ba}-\mathrm{B}$ & $3,26 \mathrm{Ba}-\mathrm{M}$ & $8,39 \mathrm{Aa}-\mathrm{M}$ & $10,55 \mathrm{Ca}-\mathrm{B}$ & $72,87 \mathrm{Ac}-\mathrm{A}$ \\
\hline
\end{tabular}

$\mathrm{cmol}_{c} \cdot \mathrm{kg}^{-1}=\mathrm{cmol}_{c} \cdot \mathrm{dm}^{-3} . \mathrm{pH}(E-$ high, $M$ - medium, $F-$ weak). exchangeable acidity and potential, sum of bases, effective and potential CTC, base and aluminum saturation ( $B$ - low, $M$ -

medium, $A$ - high)

Table 3. Need for Liming and Plastering in relation to Slope and Depth according to Author, 2020.

\begin{tabular}{|c|c|c|c|c|c|c|c|c|c|c|c|}
\hline \multicolumn{6}{|c|}{$\begin{array}{l}\text { Need for liming } \\
\text { NC (t/ha) }\end{array}$} & \multicolumn{6}{|c|}{$\begin{array}{l}\text { Áreas to be corrected with plaster, according to cassification } \mathrm{m} / 5 / .30 \% \text { at depths of } \\
0-20 \mathrm{~cm} \text { e amount of plaster (QG) }\end{array}$} \\
\hline \multirow[t]{2}{*}{$D$} & \multicolumn{3}{|c|}{ Depth cm } & SC & $\mathrm{PF}$ & $\begin{array}{l}25 \% \text { da NC } \\
0,25\end{array}$ & & $\begin{array}{l}\mathrm{SC} \\
100\end{array}$ & & $\begin{array}{l}\mathrm{EC} \\
20\end{array}$ & \\
\hline & $0-20$ & $20-40$ & $40-60$ & 100 & 7 & $\begin{array}{l}\mathrm{NG} \\
0-20 \mathrm{~cm}\end{array}$ & QG & $\begin{array}{l}\mathrm{NG} \\
20-40 \mathrm{~cm}\end{array}$ & QG & NG & QG \\
\hline $\mathrm{T}$ & 1,31 & 2,44 & 2,58 & 0,70 & & - & - & - & - & - & - \\
\hline S & 7,75 & 7,73 & 7,86 & 4,17 & & 1,94 & 1,94 & 1,93 & 1,93 & 1,97 & 1,97 \\
\hline$P$ & 2,31 & 2,58 & 3,95 & 1,24 & & - & - & - & - & 0,99 & 0,99 \\
\hline MN & 7,09 & 7,48 & 7,67 & 3,82 & & 1,77 & 1,77 & 1,87 & 1.87 & 1,92 & 1,92 \\
\hline
\end{tabular}

PRNT(\%)-relative power of total limestone neutralization= 65\%; QC65\%-amount of limestone; HQ-quantity of plaster; $25 \%$ of the NC-25\% of the liming requirement 
The slopes that require greater correction of liming are Slope and Native Forest, with more than $7 \mathrm{t} / \mathrm{ha}$ for each depth, as the depth that increases the necessary limestone concentrations for soil correction also increases, but it is only calculated the amount of limestone for a depth of $0-20 \mathrm{~cm}$ for a PRNT of $65 \%$ (Table 3). Slope, Native Forest, Pedimento and Topo need more liming at all depths. According to Mesquita et al (2016), areas that present aluminum saturation greater than 30\% (Table 3 ) will also require correction by plaster. Both the Encosta and the Nativa Forest also need plaster correction because they have saturation $>30 \%$. In addition to these, the Order in the deepest layer of $40-60 \mathrm{~cm}$ also required plastering. The slope and the native forest demand a very similar amount of plaster when comparing each of their depths. In the 40-60 cm layer of the Order, a smaller amount of plaster will be needed for soil correction. This is due to the migration of calcium carbonates to greater depths due to excess rainfall in the region.

\section{CONCLUSION}

Aiming at a better coffee productivity in the organic cultivation system, it is necessary to carry out the soil analysis beforehand, and then correct it so that the culture receives nutrients in ideal amounts for its development. This correction can be done with the use of limestone (liming) and/or plaster (plaster). For the studied area, all slopes need liming, and the slope of Encosta and the Native Forest also need plastering so that the culture can develop properly. Toposequence influences soil fertility, acts directly on nutrient availability and agroecological systems, which use nutrient cycling to nourish the coffee tree, however, it is necessary to correct the soil, with native forest and the slope being the steepest area in the system requires more than $7 \mathrm{t} / \mathrm{ha}$ of liming and plastering around $2 \mathrm{t} / \mathrm{ha}$ on the slope and in the native forest.

\section{COMPETING INTERESTS}

Authors have declared that no competing interests exist.

\section{REFERENCES}

1. Bossolani JW, Crusciol CAC, Merloti LF, Moretti LG, Costa NR, Tsai SM, Kuramae EE. Long-term lime and gypsum amendment increase nitrogen fixation and decrease nitrification and denitrification gene abundances in the rhizosphere and soil in a tropical no-till intercropping system. Geoderm. 2020;375:1-12.

2. Mesquita CM, Rezende JE, Carvalho JS, Fabri Júnior MA, Moraes NC, et al. Manual do café: manejo de cafezais em produção. Belo Horizonte: Emater-MG. 2016;1-52.

3. Novais RF, Alvarez V, VH, Barros NF, Sources RL, Cantarutti RB, Neves JCL. Soil fertility. Viçosa: Brazilian Society of Soil Science, ed. 2007;1.

4. Soares AHV, Silva CA, Zamabalde AL. Ceressefs: an expert system for calculating the need for liming and recommending corrective. Journal of Computer Science. 2004;3(2):30.

5. Rabel DO, Motta ACV, Barbosa JZ, Melo VF, Prior SA. Depth distribution of exchangeable aluminum in acid soils: a study from subtropical Brazil. Acta Scientiarum. Agronomy. 2018;40.

6. Batista AH, Motta ACV, Reissmann CB, Schneider T, Martins IL, Hashimoto M. Liming and fertilization in Pinus taeda plantations with severe nutrient deficiency in savanna soils. Acta Scientiarum. Agronomy. 2015;37(1):117-125.

7. Rodrighero MB, Barth G, Caires EF. application of limestone with different magnesium contents and particle sizes in no-tillage system. Brazilian Journal of Soil Science. 2015;39(6): 362-379.

8. Freire LR, Baliero FC, Zonta E, Angels LHC, Lima E, Guerra JGM, et al. Manual of liming and fertilization of the state of Rio de Janeiro. Seropédica, RJ: Ed. Universidade Rural. 2013;250.

9. Gliessman SR. Agroecology: ecological processes in sustainable agriculture. Lewis Publishers. 2. ed. Porto Alegre: UFRGS; 2001.

10. Alvarenga MIN. Physical, chemical and biological properties of a Dark Red Latosol in different ecosystems. Lavras, Federal University of Lavras. (Doctoral thesis). 1996;211.

11. Jezeer RE, Santos MJ, Boot RGA, Junginger M, Verweij PA. Effects of shade and input management on economic performance of small-scale Peruvian coffee systems. Agricultural Systems. 2018;162:179-190.

12. Koppen W. Climatology: with a study of the climates of the earth. Mexico. Cult. Economic. 1948;479. 
13. Tabarelli M, Santos AMM. Uma breve descrição sobre a história natural dos Brejos Nordestinos. In Brejos de Altitude em Pernambuco e Paraíba, História Natural, Ecologia e Conservação (K.C. Porto, J.J.P. Cabral \& M. Tabarelli, eds.). Ministério do Meio Ambiente, Brasília, (série Biodiversidade,). 2004;9:17-24.

14. Embrapa. National Soil Survey and Conservation Service. In: Technical Meeting of soil Survey, 10rd ed. Rio de Janeiro: Embrapa Solos. 1979;83.

15. EMBRAPA. National Center for Soil Research. 2017. Soil analysis methods manual. 3rd ed. Rio de Janeiro: Embrapa Solos, p. 573. 2017.

16. Prezotti, Luiz Carlos; Martins, Andre Guarçoni. Soil and leaf analysis interpretation guide. Vitoria - ES: Incaper. 2013;104

17. Pulla S, Riotte J, Suresh HS, Dattaraja HS, Sukumar R. Controls of soil spatial variability in a dry Tropical Forest. Plos One. 2016;11(4):1-20.

18. Freitas FA, Kopp MM, Sousa RO, Zimmer PD, Carvalho FIF, Oliveira AC. Absorção de $\mathrm{P}, \mathrm{Mg}, \mathrm{Ca}$ e $\mathrm{K}$ e tolerância de genótipos de arroz submetidos a estresse por alumínio em sistemas hidropônicos. Cienc. Rural. 2006;36(1):72-79.

19. Zakir Hossain AKM, Koyama H, Hara T. Growth and cell wall properties of two wheat cultivars differing in their sensitivity to aluminum stress. Journal of Plant Physiology. 2006;163(1):39-47.

(c) 2021 Piscoya et al.; This is an Open Access article distributed under the terms of the Creative Commons Attribution License (http://creativecommons.org/licenses/by/4.0), which permits unrestricted use, distribution, and reproduction in any medium, provided the original work is properly cited.

Peer-review history:

The peer review history for this paper can be accessed here: https://www.sdiarticle4.com/review-history/73981 